\title{
REDES SOCIOTÉCNICAS, CONVERGÊNCIAS E PRÁTICAS DE CONSUMO CULTURAL
}

\section{SOCIETECHNIC NETWORKS, CONVERGENCES AND CULTURAL CONSUMER PRACTICES}

Marco Antônio de Almeida

\section{RESUMO}

0 artigo analisa alguns aspectos que caracterizam as práticas culturais contemporâneas mediadas pelas tecnologias de informação e comunicação (TICs). 0 objetivo é discutir as conexões entre os processos que caracterizam o que se convencionou denominar "cultura da convergência" e os processos de apropriação cultural, considerando-se aqui a dimensão do poder. Essa dimensão implica em diferentes assimetrias sociais na distribuição dos poderes político, econômico e simbólico, nem sempre consideradas pela bibliografia. 0 método empregado foi o da revisão da literatura, além de estudos de caso acerca do universo das Histórias em Quadrinhos e de estratégias de financiamento coletivo da produção cultural proporcionadas pela plataforma Catarse. Como resultado, foi possível estabelecer algumas reflexões sobre as práticas culturais e do consumo cultural no Brasil, mediadas pelas TICs. Concluímos que a presença dessas tecnologias, mesmo que problemática, enriquece e disponibiliza novos meios e recursos para a criação cultural e para a dinamização das relações sociais.

Palavras-chave: Práticas Culturais. Tecnologias de Informação e Comunicação. Redes sociotécnicas. Cultura da Convergência. Indústria Cultural.

\section{ABSTRACT}

The article analyzes some aspects that characterize contemporary cultural practices mediated by information and communication technologies (ICTs). The objective is to discuss the connections between the processes that characterize what is known as the "culture of convergence" and the processes of cultural appropriation, considering here the power dimension. This dimension implies different social asymmetries in the distribution of political, economic and symbolic powers, not always considered by the bibliography. The method used was the literature review, as well as case studies about the universe of Comic Books and strategies of collective financing of cultural production provided by the Catarse platform. As a result, it was possible to establish some reflections on cultural practices and cultural consumption in Brazil, mediated by ICTs. We conclude that the presence of these technologies, even if problematic, enriches and provides new means and resources for cultural creation and for the dynamization of social relations.

Keywords: Cultural Practices. Information and Communication Technologies. Socio-technical networks. Convergence Culture. Cultural Industry. 


\section{INTRODUÇÃO}

A proposição de uma "sociedade em rede" e suas implicações - sociais, econômicas e culturais - tem sido uma das ideias basilares das reflexões acerca da sociedade contemporânea. Em larga medida, essa arquitetura de redes é o desenvolvimento de possibilidades já anunciadas nos primórdios da informática. Naquele momento, virada dos anos 40 para os anos 50 do século $\mathrm{XX}$, duas visões se contrapunham. De um lado, a perspectiva de John Von Neumann, que considerava o computador fundamentalmente uma máquina para tratar a informação; de outro lado, a perspectiva de Norbert Wiener, que encarava o computador como uma máquina de comunicar. Nos anos iniciais de desenvolvimento da informática, prevaleceu a primeira visão, e toda inovação tendia a reforçar os desempenhos internos da máquina, suas capacidades de armazenamento de dados e de autonomia em relação ao ambiente (BRETON; PROULX, 2002). A Internet desenvolve-se a partir da interação entre pesquisa científica fundamental, programas militares e contracultura radical libertária posteriormente, o empreendedorismo empresarial fará, segundo Manuel Castells (2003), o gancho da Internet com a sociedade.

As redes P2P (peer to peer, ponto a ponto) são uma das principais características da Internet. Tratam-se, basicamente, de uma arquitetura de redes de computadores na qual cada um dos pontos (ou nós) da rede desempenha funções tanto de "cliente" quanto de "servidor", possibilitando compartilhamentos de serviços e de dados sem a necessidade de um servidor central. Com a possibilidade de serem configuradas em diversos lugares - em casa, nas empresas e, principalmente, na Internet - as redes P2P logo se tornaram imensamente populares e presentes no cotidiano das sociedades. $\mathrm{Na}$ Internet, estas redes podem ser utilizadas para compartilhar músicas, vídeos, imagens, dados, enfim, qualquer conteúdo em formato digital. Em razão do grau de capilaridade alcançado com estas redes e o advento das tecnologias de informação e comunicação (TICs), a digitalização e difusão dos conteúdos artístico-culturais, bem como a expansão das práticas de consumo e as experiências de fruição cultural, dentro e fora do ambiente doméstico, vêm atraindo as atenções de pesquisadores no Brasil e no mundo.

$\mathrm{O}$ alto grau de capilaridade proporcionado pelo advento das TICs, a digitalização e difusão dos conteúdos artístico-culturais e a expansão das práticas de consumo e de fruição cultural, nos espaços domésticos e fora deles, sinalizam o papel cada vez mais central que a cultura ocupa no cotidiano das pessoas. Seria extremamente pretensioso, e 
quase inviável, querer traçar um panorama das principais teorias e ideias que se constituíram a respeito nas duas ou três últimas décadas. Desse modo, elegemos alguns pontos que emergem das relações entre cultura e TICs para propor algumas questões e problematizar o debate em torno das práticas culturais e do consumo cultural no Brasil contemporâneo. Interessam-nos, particularmente, as conexões entre os processos que caracterizam o que se convencionou denominar "cultura da convergência" (JENKINS, 2009) e os processos de apropriação cultural, considerando-se aqui a dimensão do poder. Essa dimensão implica em diferentes assimetrias sociais - na distribuição do poder político, do poder econômico e do poder simbólico - nem sempre consideradas pelos autores que trabalharam com estas questões. Procuraremos desdobrar a discussão para incluirmos considerações acerca de como as diferenças contextuais - históricas, sociais e culturais - introduzem importantes nuances às perspectivas implícitas na ideia de uma cultura da convergência e nas formas pelas quais ela se relaciona aos processos de apropriação cultural. Nas duas próximas seções, faremos uma breve revisão da literatura a respeito, além de nos determos sobre dois estudos de caso: um relativo ao cenário das histórias em quadrinhos no Brasil, e sua relação com a Internet, e outro acerca do funcionamento de uma plataforma de financiamento público de projetos culturais, a Catarse.

\section{CULTURA DA CONVERGÊNCIA, CIRCULAÇÃO E APROPRIAÇÃo CULTURAL}

A concepção de uma cultura da convergência repousa na constatação, para Jenkins (2009), de que vivemos um momento de colisão entre novas e velhas mídias, entre produtores e receptores. Ele estabelece este diagnóstico a partir da relação entre três conceitos: convergência dos meios de comunicação, cultura participativa e inteligência coletiva. A convergência dos meios de comunicação não é um fato exclusivamente tecnológico, que ocorreria apenas por meio de aparatos cada vez mais sofisticados - na verdade, a "convergência ocorre dentro dos cérebros de consumidores individuais e em suas interações sociais com os outros." (JENKINS, 2009, p. 30). Indivíduos e grupos constroem seus imaginários próprios, costurando e conectando pedaços e fragmentos de informações extraídas do fluxo midiático, transformando-os em recursos para a compreensão da vida cotidiana. Aqui, o autor recorre ao conceito de 
“inteligência coletiva” de Pierre Lévy (1998): na medida em que existem mais informações sobre determinado assunto do que um único indivíduo ou grupo possa efetivamente se apropriar, há um incentivo extra para que conversem entre si sobre a mídia que consomem.

Jenkins (2009) procura reforçar a concepção de que esse processo não se restringe à mudança exclusivamente técnica, mas que possui aspectos socioculturais. 0 foco maior de seu interesse é nas mudanças de "protocolos" - práticas culturais socialmente reconhecidas que se estabeleceram ao redor dessas tecnologias -, mais que nas mudanças de tecnologia em si.

Aqui é possível estabelecer alguns paralelos com Neal Postman (1994), que aponta que o impacto das mudanças tecnológicas modifica e redimensiona nossa visão de mundo, gerando uma redistribuição do poder simbólico e de novas fontes de legitimidade. Nesse sentido, Jenkins (2009) afirmará que a convergência permite aos "usuários" novas formas de controlar seu acesso às mídias e a seus conteúdos, bem como produzir e distribuir conteúdos produzidos por eles - com resultados criativos ou catastróficos. Não se trata, como se pode perceber, de um processo linear e cumulativo, mas de um processo de desenvolvimento desigual, que envolve produtores e consumidores e as diferentes clivagens - internas e externas - existentes entre eles e os recursos que possuem. Desse modo, "num futuro próximo, a convergência será uma espécie de gambiarra - uma amarração improvisada entre as diferentes tecnologias midiáticas - em vez de um sistema completamente integrado." (JENKINS, 2009, p. 45).

As mudanças na infraestrutura tecnológica decorrem não apenas das batalhas jurídicas e das fusões empresariais que estão alimentando a convergência midiática, mas também das transformações culturais em curso. A convergência é um processo ambivalente, partindo tanto das corporações (de cima para baixo) quanto dos consumidores (de baixo para cima). Entretanto, Jenkins reconhece que nem todos os consumidores possuem as habilidades e os recursos necessários para que sejam participantes plenos das práticas culturais que descreve. Para muitas das atividades às quais ele faz referência, mais que o acesso às tecnologias, torna-se necessária uma maior familiaridade com os novos tipos de interação social que elas permitem e um domínio mais pleno das habilidades conceituais relacionadas à convergência das mídias. Jenkins traça sua cartografia exploratória dessas novas práticas culturais interativas proporcionadas pela tecnologia digital a partir, principalmente, da reelaboração dos 
conteúdos de mídia, proporcionados pelas práticas colaborativas de determinados grupos - em particular, comunidades de fãs (JENKINS, 2009).

Embora se concentre no cenário norte-americano, na medida em que as redes informacionais vão recobrindo cada vez mais o planeta, assim como a metalinguagem digital vai absorvendo a produção imaterial dos diversos grupos sociais, essas práticas de recombinação e de hibridização vão se tornando cada vez mais frequentes. Para ilustrar melhor as ideias e os processos presentes nessa concepção de "cultura da convergência", tomaremos, como exemplo, algumas dinâmicas que têm caracterizado o campo das histórias em quadrinhos (HQs) no Brasil. Trata-se de um objeto estratégico do ponto de vista heurístico, na medida em que possibilita a problematização de relações como cultura local X cultura global, cultura mainstream X cultura de nicho, etc. Refletir acerca desse cenário permite desdobrar a discussão para incluirmos considerações acerca de como as diferenças contextuais - históricas, sociais e culturais introduzem importantes nuances às perspectivas implícitas na ideia de uma cultura da convergência e nas formas pelas quais ela se relaciona aos processos de apropriação cultural. Seguiremos, em linhas gerais, a exposição de Santos (2014). Esta incursão pode tornar mais evidente como os circuitos mainstream e alternativo se cruzam por meio das práticas culturais ativas dos "consumidores" (ou "prosumers", os produtoresconsumidores, como os denomina Jenkins). Além disso, as HQs são um excelente ponto de partida para compreender a maneira pela qual conteúdos culturais circulam/dialogam entre diferentes formas e suportes - o processo de constituição de narrativas transmidiáticas, apontado por Jenkins (2009) e desenvolvido por Scolari (2015).

\subsection{HISTÓRIAS EM QUADRINHOS, CULTURA DA CONVERGÊNCIA E INTERNET}

A Panini, através da Panini Comics e Panini Books, é atualmente, no Brasil, a responsável pela distribuição das publicações dos dois gigantes dos quadrinhos estadunidenses: DC Comics e Marvel Comics. Por meio de uma parceria com a Salvat, a Panini Comics vem distribuindo quinzenalmente nas bancas de todo o Brasil a "Coleção Oficial de Graphic Novels da Marvel", composta por 60 álbuns com uma boa relação custo-benefício, considerando o trabalho gráfico: capa dura, folhas resistentes e bem impressas. Rapidamente, a página brasileira da Salvat no Facebook (Salvat Marvel 
Graphic Novels) foi tomada por aficionados em quadrinhos. A ideia original era disponibilizar as histórias somente nos estados de São Paulo, Rio de Janeiro, Minas Gerais e Paraíba, mas a demanda e as reclamações foram tão grandes que tornaram a distribuição nacional. 0 apelo dos usuários-leitores demonstrou, nesse caso, que um agrupamento coletivo desterritorializado pode propor, apelar ou ainda sugerir modificações no modelo comercial adotado previamente pela Salvat. 0 impacto persistiu, e o número de álbuns foi elevado para 80, além da criação de uma segunda linha de publicações com os “Grandes Heróis Marvel”.

Entretanto, há que se considerar que existe um repertório acumulado, uma base bibliográfica relacionada ao universo de heróis e histórias da Marvel, com mais de 50 anos de publicações, contemplando inúmeros personagens, heróis e vilões relacionados entre si em diversos arcos de histórias que constituem esse universo. Para um amante dos quadrinhos (e, muito provavelmente, um ávido colecionador), isso talvez não seja um problema. Mas e para os leitores "leigos", ou recém-iniciados a esse universo, o que fazer? Algumas iniciativas resgatam o passado das HQs, como a "Biblioteca Histórica da Marvel" (ou, para o caso do universo da DC Comics, o "Arquivo de Casos Inexplicáveis" do Batman, compilação organizada pelo roteirista Grant Morrison, com histórias produzidas entre 1951 e 1964). Voltando ao universo Marvel, a coleção da Salvat não irá cobrir toda essa informação acumulada. Assim, dada a impossibilidade de recorrer à coleção da Salvat, e a provável indisponibilidade de estoque nas bancas, livrarias e lojas especializadas, o leitor novato muito provavelmente recorre à Internet, mais precisamente aos sites de compartilhamento onde uma comunidade viva de leitores disponibiliza, compartilha e dissemina as histórias em quadrinhos de forma rápida, prática e com um grande atrativo: gratuitamente (SANTOS, 2014).

Sites, como o HQ Online, disponibilizam em tela histórias não apenas da Marvel e da DC, mas também de editoras como a Dark Horse (Conan, o Bárbaro, 300, Hellboy), Vertigo (Sandman, Vampiro Americano, Hellblazer), Image (The Walking Dead e Spawn) e Wildstorm (Resident Evil e Wildcats). Os efeitos da reverberação cultural do site podem ser mensurados pela quantidade de usuários presentes na página do HQ Online no Facebook. São mais de 11 mil usuários que a cada nova edição disponibilizada demandam por mais, ansiosos por novas descobertas, releituras e interpretações. Mas o ponto a ser analisado não se refere a um site específico, mas sim à organização 
fragmentada de entusiastas que disponibilizam todo o acervo histórico de Marvel e DC Comics.

Podemos relacionar este processo a um dos papéis centrais da Internet na exposição ou até mesmo na criação dos nichos culturais que desafiam o estabelecimento legal da indústria cultural que determina o que deve ou não estar em evidência. Trata-se de uma constatação de que o fenômeno nostálgico dessa juvenilização simboliza a importância, a relevância e a condição histórica da cultura pop industrializada que, ao que parece, vem se tornando um bem cada vez mais efêmero. Trata-se ainda da relação estabelecida principalmente a partir da dinâmica de associações de fãs em torno dessas manifestações culturais. Existe aqui o mesmo princípio de desintermediação por meio do qual Lévy (2000) compreende os usuários como agentes fundamentais de transformação no meio digital. Em sentido semelhante, podemos tratar da vinculação à atividade crítica como componente de mediação entre usuários e os produtos culturais o que, com o advento da Internet, das comunidades virtuais, redes sociais e até mesmo da pirataria, configuram novos sentidos a este movimento crítico, inserindo os usuários como participantes ativos nos processos de troca e reconhecimento: "Se, no passado, coube à crítica fazer a mediação destas informações para o público melhor compreender as obras, agora, muitas vezes, é uma parcela do próprio público que se propõe a assumir essa tarefa." (ALMEIDA, 2009, p. 193).

A apropriação não ocorre apenas a partir dos produtos, das histórias em quadrinhos em si. É, também, uma construção coletiva em torno deste vasto universo, que reúne usuários-leitores em torno de mecanismos de disseminação a partir das páginas wiki. Tanto Marvel quanto DC Comics ${ }^{1}$ possuem páginas desenvolvidas primordialmente pela união dos usuários; um importante componente aditivo tanto na busca pelas cópias digitalizadas, como também pelos produtos lançados semanalmente, disponíveis em bancas, livrarias e até mesmo em sebos (SANTOS, 2014).

Não fosse o bastante, ainda existe um componente intertextual que fortalece essa relação, o diálogo com as formas já estabelecidas de produção artístico-cultural que configuram um horizonte de expectativas para essa mesma produção (ALMEIDA, 2009).

\footnotetext{
${ }^{1}$ A Marvel Database, página colaborativa que reúne artigos do universo Marvel, possui mais de 125 mil artigos (escritos em inglês). A DC Comics Database, por sua vez, abrange um número relativamente menor se comparada com sua "arquirrival" editorial. São 82.515 artigos que, assim como na Marvel Database, podem ser editados pelos usuários. Este apelo, inclusive, ajuda a manter as páginas sempre atualizadas, seja em conteúdo ou ainda na diagramação dos textos, que podem ser corrigidos, ampliados, recortados, sempre visando à qualidade, fidedignidade e facilidade em sua leitura.
} 
São produções cinematográficas que tomaram conta das telas de cinema, (re)introduzindo um subgênero dentro dos filmes de ação. 0 ápice desta relação ocorreu com o ambicioso projeto liderado pela Marvel Studios na recriação do multiverso sequencial dos quadrinhos para o universo cinematográfico. Outro mecanismo intertextual dos mais interessantes ocorre hoje com os videogames, que apresentam referências que inclusive vão além dos quadrinhos. ${ }^{2}$ Trata-se de uma verdadeira epopeia referencial, que traz elementos vistos na TV, pelas séries e desenhos clássicos, nos filmes e até mesmo nos demais personagens do universo DC (SANTOS, 2014).

Essas referências, graças às redes sociais e comunidades virtuais, são passíveis de ser decifradas e tornam possíveis as discussões acerca dos significados expressos nas mensagens, dos universos do qual fazem parte e até mesmo tornam possíveis interações entre os usuários, incluindo um elemento lúdico de provocações sobre quem achou o maior número de referências. Esta última questão, inclusive, revela um componente investigativo nos jogadores, que, por seu turno, torna-se uma estratégica ferramenta cooperativa que culmina com os "detonados": ${ }^{3}$ os jogadores não precisam mais recorrer às publicações especializadas para desvendar seus jogos, encontrar referências (e o universo dos videogames talvez seja o mais rico neste sentido) e passar obstáculos. Uma vez que se apropriam dos meios de produção, eles podem prover a comunidade de jogadores com vídeos, podcasts e artigos igualmente ricos em detalhes e em qualidade, se comparados ao universo editorial especializado. Este, por sua vez, ganha novos subsídios para produzir novos e incrementados conteúdos.

Finalmente, outro ponto interessante é que a distribuição dos quadrinhos pela Internet não se dá apenas pela apropriação dos usuários-leitores das suas histórias favoritas. Existe uma crescente comunidade de roteiristas e desenhistas independentes que querem somente disponibilizar o seu trabalho de forma simples e acessível.

\footnotetext{
${ }^{2}$ Mais precisamente pela série de jogos produzidos pela Rocksteady e Warner Games: os episódios Arkham, de Batman, tanto Batman: Arkham Asylum (2009), Batman: Arkham City (2011) e Batman: Arkham Origins (2013). Os jogadores são bombardeados com referências a todo o momento, como, por exemplo, as insinuações de Coringa em relação à sua origem em Batman: Arkham Origins. Alguns dos mistérios escondidos em Gotham City são apresentados neste vídeo: http://www.youtube.com/watch?v=0pcZTqHik1o\&list=TL57rZwa65a1e6ltuHC3t4FVe5ooKNaDBu. $\quad 0$ mais interessante é que se trata de uma publicação original da DC/Warner.

${ }^{3}$ Detonados são guias explicativos detalhados que oferecem aos jogadores mapas, explicações, localizações de itens e lugares secretos, tornando mais fácil a exploração pelos jogos. Geralmente atribuídos às publicações especializadas impressas, os detonados ganharam novas configurações graças ao YouTube. Os vídeos permitem uma observação mais atenta e detalhada do que fazer para vencer determinada fase do jogo, encontrar determinados itens ou ainda explorar todas as possibilidades dos mapas, com cada vez mais detalhes e referências.
} 
Utilizam, para isso, as licenças Creative Commons, não impondo barreiras legais à sua utilização por parte dos usuários, desde que, evidentemente, sejam respeitados os princípios de autoria.

Neste cenário efervescente de novidades, fora do mainstream dos universos Marvel e DC, destacam-se as histórias do Hacktoon, blog desenvolvido por Karlisson M. Bezerra. 0 projeto inicial era publicar as tirinhas da série "Nerdson Não Vai à Escola", mas o projeto cresceu, ganhou outros componentes e histórias. ${ }^{4}$ Outro blog, o Petisco, ${ }^{5}$ reúne uma série de quadrinhos online, também conhecidos como Web comics, nos mesmos moldes do Hacktoon. Cada série da Petisco é atualizada semanalmente, em dias diferentes, o que acaba configurando uma atualização diária das histórias.

Anterior a todas estas obras, a historinha dos Combo Rangers ${ }^{6}$ pode ser considerada como a precursora deste movimento da Web comic na Internet brasileira. Criada em 1998 por Fábio Yabu, a obra tinha como referência as séries conhecidas como Super Sentai. Geralmente produzidas no Japão, estas obras tratam da formação de um grupo de super-heróis que, ao receberem poderes especiais, passam a combater o crime e ameaças intergalácticas. Power Rangers, Troopers, Winspector, Kamen Raider e Changeman fazem parte deste universo. Combo Rangers misturava um estranho e escatológico senso de humor com leves toques de romance, drama e mistério; gerou tanto sucesso que motivou a migração da Internet para as publicações impressas, dando início a uma nova fase da série. Como se vê, até mesmo nos períodos iniciais da Internet brasileira já existiam usuários-produtores ansiosos por desenvolver os potenciais da grande rede em torno do seu aspecto comunicativo. Os modelos de disponibilização, graças ao incremento das atividades da pirataria, deixaram visível a existência de um público consumidor. Mais: relacionam estes públicos a outras formas, objetos e produtos culturais graças à intertextualidade; ao deixar em segundo plano o componente "profissional" do crítico e valorizar a perspectiva dos usuários, disseminando não apenas os produtos, mas derivações coletivas, empreitadas de interesses compartilhados que buscam colaborar para o acesso, disseminação e promoção cultural dos quadrinhos (ALMEIDA, 2009).

\footnotetext{
${ }^{4}$ Link da página: http://hacktoon.com. Entre as novas tirinhas, constam "Barrabin Barrabish", "Self-Aware Telecon" e "Libman \& APIboy".

${ }^{5}$ Link da página: http://petisco.org. Entre as séries da Petisco, encontramos títulos como "Beladona", "Calundu e Cacoré", "Demetrus Dante", "Valkiria", "Samsara Vortex", "Homem Grilo \& Sideralman", "Terapia”, “Nanquim Descartável”, "Pocket Comics" e "Nova Hélade”.

${ }^{6}$ Link atual da página, com as histórias das fases disponibilizadas entre os anos de 1998 e 2001: http://comborangers.com.br.
} 
As práticas dos consumidores-usuários permitiram, hoje, o acesso e a leitura de obras de acervos raros, e não apenas dos acervos da DC Comics e Marvel. Os usuáriosleitores, ao tornarem públicas estas histórias, à revelia das grandes editoras, não executam esse tipo de ação esperando muito mais ganhos simbólicos do que materiais, retomando ideais mais próximos de uma "economia da dádiva". Ao tornar este acervo público, estão ampliando a cena cultural, ao valorizar e encorajar novos leitores, produtores, novos compradores e até mesmo estudiosos. Ao exercitarem o papel de "críticos" na Internet, colaboram com que as HQs configurem-se como formas cada vez mais valorizadas de manifestação cultural, em certa medida representando e traduzindo contextos sociais de épocas, personagens e lugares.

As transformações ocasionadas pela Internet e pelo reconhecimento dos seus usuários como protagonistas no cenário cultural e social da rede não são apenas movimentos cíclicos, orientados para os "párias" culturais, que à margem dos produtos protegidos pelo copyright, se apropriariam destes para celebrar o "mundo livre". Isso sinaliza antes o reconhecimento de parte das funções sociais da cultura livre, um aceno à valorização do outro lado desta batalha, que vê benefícios (inclusive comerciais, evidentemente) na publicidade cultural. Tanto $\mathrm{Marvel}^{7}$ quanto DC Comics, ${ }^{8}$ por exemplo, já disponibilizam alguns exemplares de forma gratuita para seus usuários. Aos olhos dos leitores, que provavelmente gostariam de ter a seu dispor todas as histórias, pode parecer pouco, mas se trata de uma brecha na lógica empresarial que sinaliza um interesse de valorização da publicização por parte dos proprietários dos direitos autorais.

\subsection{TECNOLOGIA, CULTURA E PODER}

A hipertextualidade, um dos paradigmas da cultura pós-moderna, a ligação das diversas informações e referências, tende a se fortalecer cada vez mais com a libertação dos conteúdos e dos formatos de seus suportes materiais, proporcionada pelas tecnologias digitais. Por outro lado, como observa Silveira (2008, p. 86), “ao reconduzir as práticas recombinantes ao status de importância cultural global, a internet coloca em risco as atividades especializadas e de intermediação da Indústria Cultural e torna-se

\footnotetext{
${ }^{7}$ As histórias disponíveis estão na seguinte página: http://marvel.com/comics.

${ }^{8}$ As histórias disponíveis estão na seguinte página: http://www.readdcentertainment.com/free-comics.
} 
alvo de diversas tentativas de controle." Esta é a primeira questão, relativa ao poder e ao controle dos meios e das redes, que deve ser problematizada em relação às perspectivas abertas por Jenkins (2009), construídas principalmente num âmbito estadunidense, buscando situar suas observações num âmbito mais globalizado.

Vale esclarecer que, quando pensamos em poder, estamos considerando as três clássicas variedades mapeadas por Steven Lukes (1980): a capacidade de obrigar as pessoas a fazerem o que não querem fazer; a capacidade de fazer as pessoas pararem de fazer o que querem fazer e, não menos importante, o poder de formar a maneira pela qual elas pensam. Este último tipo de poder, cada vez mais disseminado pelo mundo contemporâneo, é aquele exercido pelos meios de comunicação - tradicionais ou emergentes. E isso remete, de diversas maneiras, à forma pela qual um conceito como “apropriação cultural” emerge. Resumidamente, poderíamos defini-lo como a adoção de alguns elementos específicos de uma cultura por um grupo cultural diferente. Essa definição descreve historicamente os processos de aculturação ou de assimilação, mas pode, contemporaneamente, implicar numa visão negativa em relação à aculturação de uma cultura minoritária por uma cultura dominante. Ou seja, é uma decorrência e, ao mesmo tempo, um sintoma de disputas pelo poder simbólico. Não nos alongaremos na discussão conceitual e teórica da questão, preferindo seguir a abordagem proposta por Yúdice (2006), que entende, em linhas gerais, a cultura como um recurso e a apropriação cultural como uma forma de performatividade dos sujeitos a partir desse recurso em conexão com os contextos em que se inserem.

A soberania do Estado-Nação deu lugar ao poder compartilhado do Estado em Rede. Hardt e Negri (2005), por exemplo, desenham o cenário de um mundo em guerra global permanente, porém com um caráter diferente do que a ideia de guerra possuía até o século XX. Para os autores, não se trata mais de conflitos entre Estados-Nação circunscritos a territórios específicos, nem restritos a combater grupos políticos ou indivíduos. No século XXI, a guerra se estende ao combate de conceitos e se apresenta como um conjunto de práticas que demandam uma ação permanente e desterritorializada. Trata-se, portanto, de uma disputa pela hegemonia do controle dos "aparelhos ideológicos" do ciberespaço. Simultaneamente aos procedimentos mais incisivos por parte do Império (o permanente estado de guerra total - às drogas, à pirataria, ao terrorismo), as grandes corporações também buscam controlar os 
incessantes fluxos infocomunicacionais, procurando situar-se estrategicamente como seus principais mediadores.

O ciberespaço passou a ser utilizado como um importante mediador de um amplo leque de atividades - como financiamento coletivo, resolução de problemas de maneira coletiva, troca de informações, ideias, conhecimentos e interesses socioculturais -, ampliando o capital social dos indivíduos e das comunidades formadores da rede da qual fazem parte. Nessa atual conjuntura, e com recursos das TICs, temos uma forma inédita e emergente de organização e produção cultural, assim como um novo espaço de desenvolvimento das políticas culturais, que merece ser melhor analisado e problematizado, trazendo alguns subsídios para refletir sobre as incidências locais desse processo global. Após a utilização dessas tecnologias, vemos surgir formas inéditas de produção, execução, circulação e recepção de produtos simbólicos, que contribuem de maneira decisiva para tornar a cena cultural contemporânea mais complexa (ALMEIDA, 2010).

O que nos leva de volta a Jenkins (2009) e à discussão acerca do poder dos consumidores - dos interagentes dos conteúdos e dos formatos disponíveis na Internet. Aqui, duas estratégias se fazem sentir por parte das grandes corporações: a primeira, uma ação mais direta e incisiva, que se apoia nos pressupostos legais relacionados aos direitos autorais, focada no aparato jurídico-policial (que contemplariam as duas primeiras definições de poder de Lukes). A segunda, um conjunto de ações indiretas, mas não menos eficientes, de controle do fluxo de informações pelo uso de filtros tecnológicos que funcionam, no limite, como mediações ideológicas e culturais (o que incide na terceira definição de Lukes, o poder ideológico propriamente dito).

Em relação aos direitos autorais, Jenkins (2009) cita diversos exemplos de como as grandes corporações midiáticas lidam com as comunidades de fãs e suas recriações dos universos ficcionais por elas administrados. Essas relações tanto podem ser amigáveis, no sentido de uma permissividade negociada, e até estimulada pelas corporações a partir do estabelecimento de certas regras e fronteiras mutuamente estabelecidas, de forma explícita ou tácita. Um dos exemplos fornecidos por Jenkins (2009) é o caso de George Lucas e o universo de Star Wars (Guerra nas Estrelas). Em 2000, a Lucasfilm ofereceu espaço gratuito na Web para os fãs da saga e acesso a conteúdo exclusivo para seus sites, com a condição de que tudo o que fosse por eles criado se tornaria propriedade intelectual do estúdio. Por outro lado, os escritórios de 
advocacia são prontamente acionados quando determinadas fronteiras são ultrapassadas - o que oferece interessantes disputas relativas ao entendimento do que é considerado pirataria/apropriação indébita do que é considerado paródia ou documentário, formatos que desfrutam de maior proteção sob a atual jurisprudência. Mais recentemente, este tipo de atitude voltou à baila com o universo ficcional de Star Trek (Jornada nas Estrelas). Os estúdios Paramount e CBS, que detêm os direitos da franquia, estão exigindo, através de seus advogados, uma liminar por violação de direitos autorais e propriedade intelectual porque uma fan-fiction - no caso, um filme amador produzido por fãs - demonstra ter "alta qualidade profissional". Os produtores do filme, intitulado de "Axanar", conseguiram arrecadar mais de US\$ 1 milhão em sites de financiamento coletivo e pretendem levar a briga adiante na justiça, alegando que este tipo de filme já vem sendo produzido há mais de trinta anos, e que diversas produções do gênero também já levantaram muito dinheiro (UOL, 2015).

Por outro lado, é difícil negar que as redes sociotécnicas colaborativas mostraram-se importantes para o fortalecimento de determinadas manifestações culturais. Esse processo de comunicação, suportado pela rede, cria uma identificação entre os participantes dos grupos, que, aos poucos, constituem uma comunidade de participação coletiva. Como aponta Shirky (2012), estamos vivendo um momento onde nossas vidas sofrem fortes interferências das tecnologias, através das quais transferimos atividades cotidianas de nossas vidas para o ambiente Web. Com o advento das TICs, principalmente a Internet, vemos surgir um novo modelo de ajuda ao setor cultural, que difere do mecenato. Nessa perspectiva, as plataformas de participação coletiva configuram-se como redes que se fortalecem através das trocas informacionais, importantes para o cenário cultural. A partir dessa comunicação, a comunidade inserida nessa rede passa a ser não só espectadora, mas também agente ativa no processo de produção e financiamento de projetos, funcionando também como uma plataforma de socialização. Nesses casos, as pessoas passam a ajudar os projetos tanto financeiramente quanto na produção e construção do mesmo, a partir do uso de novas práticas colaborativas, como o crowdsourcing e crowdfunding.

0 crowdsourcing, termo cunhado por Jeff Howe e Mark Robinson, refere-se à prática de empresas que buscam soluções de seus problemas internos no conhecimento coletivo produzido fora de suas dependências, numa espécie de terceirização de soluções. 0 termo crowdsourcing não possui uma tradução literal para o português, mas 
pode ser visto, de forma geral, como um modelo de criação ou produção baseado em redes de conhecimento coletivo para solucionar problemas, criar conteúdos ou inventar novos produtos de forma colaborativa (HOWE, 2009). ${ }^{9}$

Já o conceito de crowdfunding pode ser visto como parte de um conceito mais amplo de crowdsourcing, que usa o conceito de "multidão" para obter ideias, opinião e soluções a fim de desenvolver atividades colaborativas. Essa prática usa as potencialidades das redes sociotécnicas para arrecadar recursos financeiros para organizar ou produzir determinados projetos. A lógica de funcionamento do crowdfunding acontece a partir de uma junção de pequenos investimentos através de um grande número de investidores. No Brasil, é comum a tradução dessa prática pelo emprego do termo "financiamento coletivo". ${ }^{10} 0$ crowdfunding basicamente tornou viável a criação e realização de produtos culturais que estariam fora da zona de interesse da grande indústria (shows, filmes, peças de teatro, livros, HQs), com o apoio do público interessado por meio das redes estabelecidas pela Internet. As TICs permitem que os consumidores abandonem uma postura supostamente passiva, organizando-se em grupos que unem esforços e/ou destinam fundos a projetos de seu interesse, eliminando a intermediação burocrática presente na indústria cultural (VALIATI, 2013).

No Brasil, uma plataforma que se consolidou a partir desta prática, voltada para projetos culturais, foi o Catarse, que se apresenta como uma ferramenta que possibilita o financiamento de projetos criativos, incorporando artistas, designers, gamers, empreendedores, ativistas. 0 objetivo é viabilizar financeiramente seus projetos. Essas

\footnotetext{
${ }^{9}$ Dada a dificuldade de encontrar uma definição consensual para o termo crowdsourcing, Estellés-Arolas e González-Ladrón-de-Guevara (2012) realizaram um estudo comparativo de várias definições do que é crowdsourcing para chegar a uma definição global. Com base nesse estudo, eles propõem a seguinte definição: "crowdsourcing é um tipo de atividade online participativa em que um indivíduo, uma instituição, uma organização sem fins lucrativos, ou a empresa propõe a um grupo de indivíduos de diferentes conhecimentos, heterogeneidade e número, através de uma chamada flexível e aberta, o compromisso voluntário de uma tarefa. 0 compromisso da tarefa, de complexidade e modularidade variável, e em que a multidão deve participar trazendo o seu trabalho, dinheiro, conhecimento e / ou experiência, sempre implica benefício mútuo. 0 usuário receberá a satisfação de um determinado tipo de precisão, seja econômico, reconhecimento social, autoestima, ou o desenvolvimento de habilidades individuais, enquanto o crowdsourcer irá obter e utilizar a vantagem sobre o que usuário tenha trazido para o empreendimento, cuja forma dependerá do tipo de atividade desenvolvida." (ESTELLÉS-AROLAS; GONZÁLEZ-LADRÓN-DE-GUEVARA, 2012, p. 9-10, tradução nossa).

${ }^{10}$ Não existe um consenso sobre a criação do termo, mas seu uso inicial é atribuído majoritariamente ao empresário americano Michael Sullivan como o cunhador do termo crowdfunding, por volta de 2006, com o lançamento do fundavlog, uma tentativa frustrada de criação de uma incubadora de projetos e eventos relacionados com o videoblog, incluindo ferramentas informáticas de financiamento com funcionalidade simples. Embora o termo seja recente, é sabido que práticas como essa já acontecem há muito tempo, e tinham como real significado serem utilizadas para a arrecadação de fundos para filantropia.
} 
iniciativas inovadoras e criativas podem se tornar realidade a partir da colaboração direta de pessoas que se identificam com elas. ${ }^{11}$

O sistema usado pelo Catarse de "tudo ou nada" estabelece como regra que um projeto somente é considerado bem-sucedido se o valor da arrecadação mínimo for atingido ou superado. Caso isso aconteça, o realizador tem direito a retirar toda a quantia arrecadada. Se dentro do prazo estipulado o projeto não conseguir atingir os valores necessários, é considerado um projeto "malsucedido", e a plataforma tem como política devolver as arrecadações para todos os apoiadores, e o realizador do projeto não tem acesso a nenhum valor arrecadado. Em 29 de abril de 2014, o Catarse após três anos e três meses no ar, chegou à marca de 1.000 projetos financiados, o que equivalia a $56 \%$ de todas as iniciativas que passaram pela plataforma.

Figura 1 - Divisão do dinheiro arrecadado por área.

\section{Divisão dos $\mathrm{R} \$$ 13,78 milhões arrecadados}

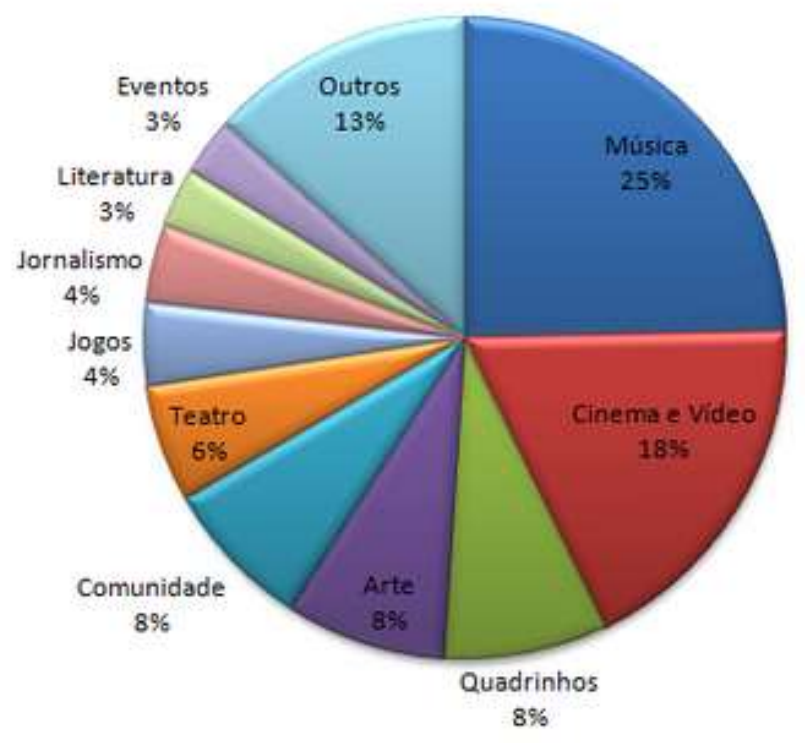

Fonte: (CARUSO, 2014).

Ao analisarmos os dados, é perceptível que as arrecadações ligadas às práticas culturais são o foco do Catarse. Se considerarmos os setores de Música, Cinema e Vídeo, Quadrinhos, Arte, Teatro e Literatura, constataremos que 69\% das arrecadações da plataforma foram direcionadas ao setor cultural. Outros dados importantes relacionam-

11 Para mais informações, acesse: http://suporte.catarse.me/hc/pt-br/articles/201982466-0-que\%C3\%A9-e-como-funciona-o-Catarse. 
se com os canais em que seus colaboradores buscam informação. Analisando os números apresentados, podemos observar que as TICs são indispensáveis para o sucesso dessa prática, configurando-se como recurso para as pessoas que optam por buscar diretamente as informações, não desempenhando mais o papel de usuários passivos, inclusive sinalizando, em alguns casos, que anseiam não só obter conteúdo, mas também participar. Percebe-se, assim, que o setor cultural passa por um processo de transformação, que implica não só no acesso aos conteúdos, mas também em ações que visam estabelecer vínculos identitários e de pertencimento a determinados grupos culturais. Com isso, o setor pode se fortalecer e se organizar através de redes que criem uma nova forma de produção/relação cultural. Os meios tradicionais de comunicação veem cada vez mais seu público buscar não só por informação através das redes sociotécnicas, mas também por identidade (ALVES, 2014).

Figura 2 - Canais onde colaboradores do Catarse buscam informações.

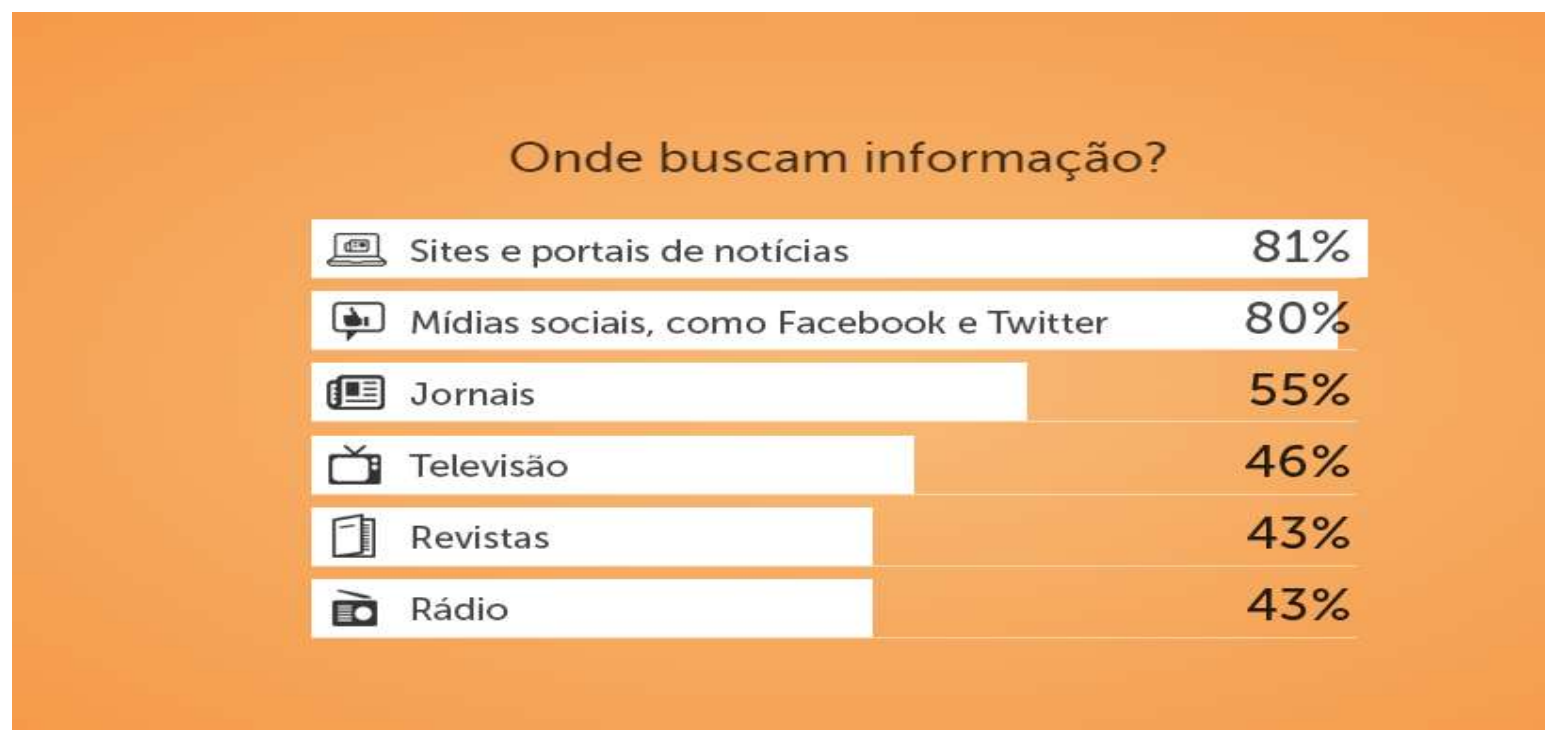

Fonte: (CATARSE/CHORUS, 2014).

A pesquisa efetuada pela plataforma Catarse ajuda-nos a compreender melhor os processos de financiamento coletivo (FC), apresentando dados que reforçam a ideia de um alargamento do setor cultural com a prática do FC. A figura a seguir mostra que $52 \%$ das pessoas que contribuem com o financiamento coletivo têm interesse em financiar projetos ligados às atividades culturais. Trata-se de um valor significativo, já que a prática de financiamento coletivo ainda é muito recente no país, principalmente quando se trata de financiamento cultural. 
Figura 3 - Projetos que mais despertam interesse na plataforma.

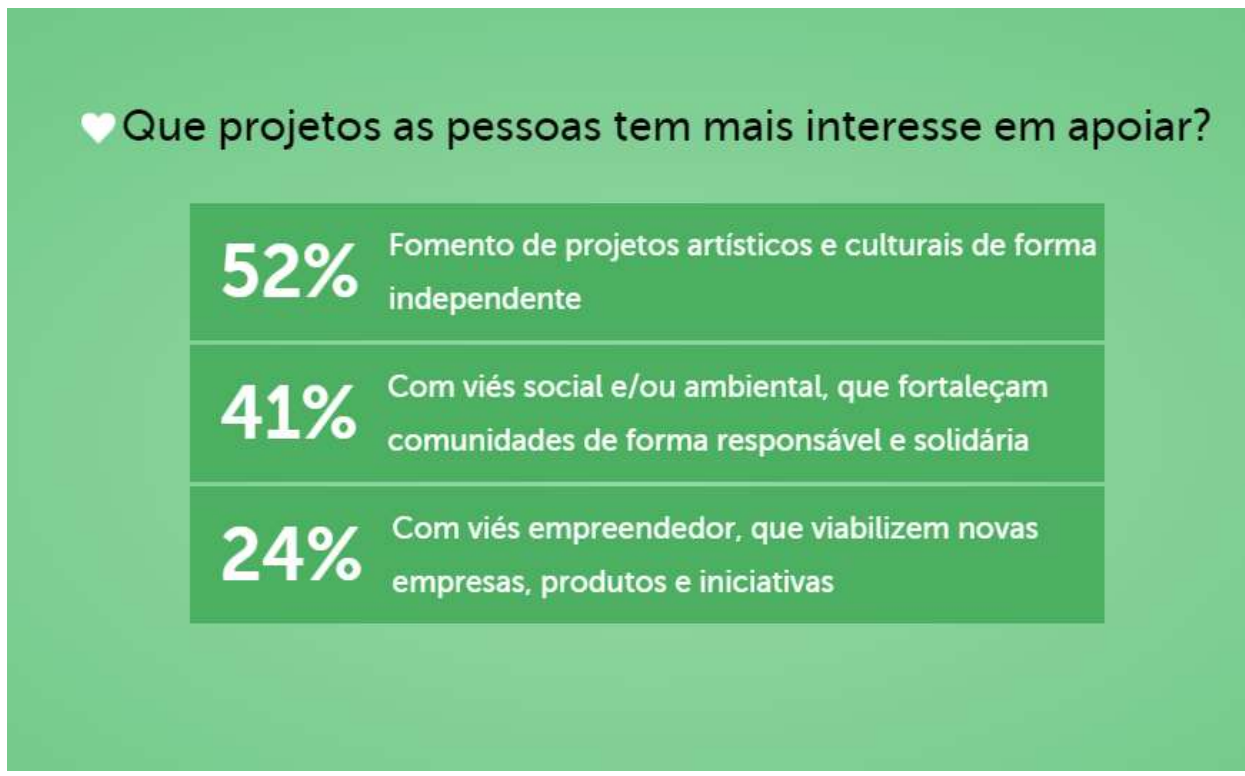

Fonte: (CATARSE/CHORUS, 2014).

Um ponto importante dentro das características de interesse dos colaboradores foi a busca por projetos ligados à área de educação, porém é o setor que apresenta menor quantidade de projetos relevantes. A educação e a cultura são, hipoteticamente, setores que se retroalimentam, e esses dados alertam que o fortalecimento do setor cultural pode ser ainda maior, na medida em que a educação for explorando essas novas potencialidades - e que passe a investir em formas de construção da educação baseada na participação coletiva.

A plataforma também pode ser vista como um espaço social e informacional, que não só dá condições para os proponentes tentarem financiar seus projetos, como também permite fazer contatos e trocar experiência com outros proponentes. ${ }^{12}$ Ou seja, a plataforma cria formas para os participantes darem feedbacks a respeito de seus trabalhos e ajudarem dando dicas e mostrando suas experiências aos proponentes de novos projetos. O espaço não se restringe aos projetos bem-sucedidos. Os projetos malsucedidos também receberam feedbacks, buscando entender qual o motivo de não terem alcançado suas metas. A partir da contraposição de estratégias bem e malsucedidas, foi possível construir um conhecimento, uma "expertise" voltada à

\footnotetext{
$12 \mathrm{Um}$ exemplo é o espaço cedido no blog Catarse para a fala de Caio Tendolini, onde ele afirma que o crowdfunding é mais "Crowd" do que "Funding", e diz como o filme "Belo Monte" conseguiu muito mais do que $\mathrm{R} \$ 140$ mil via campanha no Catarse.
} 
capacitação dos sujeitos, permitindo-lhes construir projetos com maiores chances de obterem resultados positivos.

Assim, além de se constituir como uma rede de interesse econômico-cultural, a rede Catarse também se apresenta como um espaço de trocas sociais e informacionais. A rede constituída é uma forma de fortalecimento das atividades culturais, pois alcança um grande público, possibilitando trocas informacionais que vão configurando um conhecimento compartilhável, constituído a partir da práxis dos atores envolvidos. A manutenção da rede passa a ser um dos elementos para alcançar êxito: é necessário avaliar o que fazer para melhorar, como se organizar para manter os apoiadores informados e se sentindo parte do projeto, pois quem apoia o faz por se identificar com a causa, ou por motivações que o faz se sentir de alguma forma integrante daquele projeto (SHIRKY, 2012).

A plataforma trabalha para incentivar essa participação com esquema de apoio baseado em recompensas, mas, ao observarmos as participações e como o próprio Catarse as menciona em seu site, não são essas o principal elemento de motivação. Quando se trata de atividades culturais, as pessoas que financiam os projetos os fazem para fortalecer aquela determinada atividade cultural, ou para satisfazerem seu desejo social de se sentir participando. As doações têm grande impacto nas formas de organizar e produzir atividades culturais, pois podem ser vistas como uma alternativa para os produtores culturais encontrarem formas de desburocratizar sua atividade, podendo desenvolvê-la de forma mais independente, sem ter que produzir determinadas atividades baseadas na imposição de uma instituição financiadora. Essa relação apoiador/realizador encontrada no Catarse pode sinalizar também para outro tipo de dinâmica social. Ao considerarmos que o apoiador não conhece o realizador, e que no processo de resolver financiá-lo possa manifestar a vontade de conhecer o projeto pessoalmente, pode-se antever uma relação que sai da esfera "virtual" e caminha para um possível encontro presencial. Esse é outro potencial estratégico das redes sociotécnicas colaborativas, o de possibilitar que as relações que acontecem inicialmente no ambiente online possam ser transferir para o ambiente off-line - no limite, eliminando essa distinção e considerando essas atividades como um continuum (ALMEIDA, 2010).

Por outro lado, Primo (2015) aponta algumas das formas pelas quais a indústria da Web 2.0 apropria-se do trabalho dos consumidores sem que eles tenham 
conhecimento de, muitas vezes, estar participando da construção de commodities digitais. $\mathrm{O}$ consumo online possui um preço, que é pago com trabalho cognitivo por parte dos usuários (por exemplo, fornecendo dados próprios, respondendo pesquisas, resolvendo captchas e outros códigos). Muitas dessas informações serão utilizadas para o encaminhamento de publicidade ou oferta de vendas. Numa "economia da atenção", nossa percepção em relação a estes estímulos é um bem muito valioso (PRIMO, 2015). Em relação às fanfics (fan fictions), Primo (2015) observa que são uma modalidade de trabalho gratuito, que privilegia a grande indústria. Entretanto, grande parte dos fãs sabe disso, mas se contenta com a satisfação pessoal de participar do processo, embora reconhecendo os riscos de sofrer processos legais por parte dos detentores dos direitos autorais. Assim, os fãs "tampouco sentem estarem colaborando com a indústria, conferindo valor afetivo adicional às mercadorias culturais que seus nichos consomem. Em vez disso pensam estar afrontando as imposições das indústrias culturais." (PRIMO, 2015, p. 82).

Embora parte da crítica de Primo (2015) seja aplicável aos mecanismos de financiamento coletivo descritos anteriormente, por outro lado é necessário reconhecer que, de fato, eles se configuraram como alternativas de viabilização de projetos culturais por meio do associativismo, que conseguiram ultrapassar os limites impostos pela grande indústria cultural e construir seus nichos. 0 desenvolvimento de projetos individuais e coletivos nas sociedades contemporâneas encontra na Internet a possibilidade de uma extensão dos limites físicos do cotidiano, gerando canais de comunicação, comunidades e redes de afinidades. Castells (2003) já observava que o êxito das comunidades virtuais geralmente se relaciona ao fato delas estarem voltadas para a execução de tarefas ou perseguir interesses comuns. Outro ponto importante é estarmos lidando com os processos do mundo globalizado, levando informações culturais para dentro de uma plataforma que pode ser acessada pelo mundo todo e que, independente do lugar onde essas pessoas estejam, elas podem contribuir com o projeto.

Já em relação às mediações ideológicas e tecnoculturais, para Alberto Melucci (2001, p. 39), "nos sistemas complexos, a capacidade de intervenção sobre a ordem simbólica não só se generaliza em toda a sociedade, mas se move também em direção ao indivíduo." No passado, o pertencimento era pensado em termos de uma comunidade ou de um grupo; agora o indivíduo é o ponto terminal dos processos de regulação. 0 mundo contemporâneo coloca à disposição dos indivíduos uma gama inédita de recursos 
simbólicos que estendem seu potencial de individuação (autonomia/autorrealização). Dessa forma, para garantir a própria integração, a sociedade não pode ficar restrita à regulação da apropriação e distribuição de recursos, devendo estender seu controle sobre os níveis simbólicos das ações - as esferas que constituem o sentido e a motivação do agir. Desse modo, Melucci (2001) considera o conhecimento como um recurso fundamental para os "atores conflituais": permite revelar a natureza real das relações sociais por trás das aparências que os aparatos dominantes tendem a impor à vida coletiva. Nas sociedades cada vez mais complexas, a cultura torna-se, por excelência, o terreno estratégico dos conflitos.

Um dos campos privilegiados desse conflito apontado por Melucci (2001) é a Internet. Um dos paradoxos da Internet é que milhares de cidadãos - cada vez mais configurados em consumidores e/ou usuários - se utilizam desse espaço público das plataformas digitais, desfrutando de um serviço "público" propiciado por corporações particulares. Pesquisas em diversas partes do mundo mostram que o acesso à Internet tem como atrativos principais o lazer e a busca de informação, mas que isso é mediado fortemente pelas redes sociais, em particular o Facebook e o YouTube (por exemplo, vide os dados da OEI, 2014 e da SECOM, 2014). A utilização dessas redes, bem como do buscador Google e dos grandes portais como o Yahoo! e o UOL, representa, para a maioria dos usuários na maioria do tempo, a experiência por excelência de navegação na Internet. Uma realidade prática que depõe contra a propalada diversidade da Internet, reduzindo as potencialidades de navegação quase ao velho modelo comunicacional do broadcasting, ${ }^{13}$ diminuindo para os usuários as possibilidades dialógicas e de acesso a produções culturais fora do mainstream. O Facebook age para trazer inúmeros serviços e conteúdos hoje disponíveis na Web para dentro de sua plataforma. Essa concentração possibilita mais acesso à sua rede, o que trará ainda mais poder econômico para a corporação de Zuckerberg.

\footnotetext{
${ }^{13} \mathrm{O}$ broadcasting seria a transmissão massiva de um mesmo conteúdo para vários receptores, que caracterizaria os meios de comunicação de massa tradicionais, em oposição às possibilidades dialógicas da transmissão peer-to-peer possibilitadas pela Internet, capazes de quebrar esse monopólio da transmissão da informação.
} 


\section{CONVERGÊNCIA, APROPRIAÇÕES CULTURAIS E FLUXOS INFOCOMUNICACIONAIS14}

Para Jenkins (2009, p. 193), “cultura popular é o que acontece quando a cultura de massa é empurrada de volta à cultura tradicional." Ele entende esta última como uma economia cultural alternativa à indústria cultural - que nunca a levou seriamente em conta até a emergência da cultura da convergência. Na sua perspectiva, portanto, a cultura popular seria a resultante das batalhas entre produtores e receptores pela apropriação dos conteúdos da mídia (convergência corporativa $\leftrightarrow$ convergência alternativa). Jenkins vê na Web, e nas suas possibilidades de colaboração e compartilhamento, um estímulo para a criatividade e a expressão dos indivíduos comuns: "uma vez que se tem um sistema de distribuição confiável, a produção da cultura tradicional começa a florescer novamente, da noite para o dia." (JENKINS, 2009, p. 193).

Quando Jenkins aborda a ideia de uma cultura "popular", na verdade está empregando o termo num sentido diferente do que ele é habitualmente utilizado no Brasil e em grande parte da América Latina. Do ponto de vista da especificidade da cultura americana, o trabalho de Neil Gabler (1999) situa historicamente as referências sobre as quais as concepções de Jenkins se estruturam. Ao analisar as diferenças entre a Europa e os EUA, Gabler (1999) aponta como o entretenimento praticamente não se propagou na primeira e fez da segunda seu reino. No caso europeu, pesaram a censura religiosa e a instituição cultural secular (as barreiras entre alta e baixa cultura estabelecidas pelas classes dominantes). No caso dos EUA, esses fatores pesaram menos e possibilitaram a construção de uma indústria do entretenimento que se tornou a base do que Jenkins compreende como cultura popular. Já para o caso brasileiro, Renato Ortiz (1988) argumenta que, durante muito tempo, não houve uma nítida diferença entre um polo de produção restrita e um de produção ampliada, devido à fragilidade do capitalismo existente, no qual a dimensão dos bens simbólicos não conseguia expressarse completamente. Decorreu daí a fraca especialização dos setores da produção cultural. Até hoje, algumas das consequências de tal tipo de confusão - o imbricamento dos campos culturais - ainda podem ser sentidas na produção cultural brasileira

\footnotetext{
${ }^{14}$ Nesta seção, retomo em linhas gerais o argumento desenvolvido em: ALMEIDA, Marco Antônio de. Processos culturais \& convergências tecnosociais. Revista do Centro de Pesquisa e Formação do SESC, n. 2 , jun./2016.
} 
contemporânea. Além disso, para a análise de determinados setores dessa produção cultural, concorrem outros fatores específicos, que vão do papel do Estado à influência de determinadas correntes estéticas pós-modernas, passando também pelos influxos da globalização.

Há certa generalidade nessas observações, mas que decorrem da intenção de demonstrar as especificidades da constituição das concepções em torno do campo cultural no Brasil, que pode ser estendida em larga medida ao restante da América Latina, particularmente no que concerne ao trânsito entre as esferas do erudito, do tradicional e do "popular de massa", na expressão de Jesús Martín-Barbero (1997). Para ele, numa perspectiva próxima à de Ortiz, o período de industrialização e modernização da América Latina dos anos 30 a 50 do século XX, e a correlata expansão urbana que desencadeou, foi marcado por uma dupla interpelação. Segundo Martín-Barbero, esta dupla interpelação caracterizaria, ao mesmo tempo, a ambiguidade e a eficácia do apelo às tradições na construção de uma cultura nacional e, principalmente, "o papel peculiar de certos meios massivos que, como o cinema e o rádio, constroem seu discurso com base na continuidade do imaginário de massa com a memória narrativa, cênica e iconográfica popular, na proposta de um imaginário e uma sensibilidade nacionais." (MARTÍN-BARBERO, 1997, p. 228).

Néstor Garcia Canclini (1997) observa que um dos principais efeitos desse processo para a dinâmica contemporânea do campo da produção cultural, particularmente na América Latina, é que a interação crescente entre o culto, o popular e o massivo acaba por abrandar as fronteiras entre seus praticantes e seus estilos. Desse modo, compreende que a reorganização atual da cultura não é um processo linear, que “a necessidade de expansão dos mercados culturais populariza os bens de elite e introduz as mensagens massivas na esfera ilustrada" (CANCLINI, 1997, p. 360), o que não significa que a defesa dos capitais simbólicos específicos e a marcação de fronteiras de distinção na luta pelo controle dos processos culturais tenham cessado. Por outro lado, introduz nuances diferentes em relação aos processos de apropriação cultural que uma cultura da convergência, nos termos propostos por Jenkins (2009), poderia proporcionar.

Desse modo, a Internet reconfigura os papéis no jogo de disputa hegemônica pelo poder entre grandes corporações, Estados-Nação e comunidades culturais. George Yúdice (2015) aponta alguns dos paradoxos que envolvem as novas tecnologias digitais 
em sua relação com os Estados-Nação e com a cultura. De uma perspectiva ideal, as esferas públicas que se consolidam na Modernidade europeia, a partir do final do século XVIII, eram principalmente físicas: as pessoas iam a teatros, praças, cafés, constituindo um conjunto de cidadãos. Hoje, esse espaço público se transladou para as plataformas digitais, e o que antes pensávamos ser um cidadão, tornou-se, cada vez mais, um usuário, sobretudo entre os jovens. São esses usuários que configuram uma situação sui generis, na medida em que desfrutam de um serviço público proporcionado por entidades privadas que o fazem melhor que qualquer Estado do mundo - Yúdice (2015) refere-se, nesse caso, aos provedores de Internet como Google, Facebook e outros. Para Yúdice (2015), as plataformas digitais em mãos de setores privados estão disputando o poder com os Estados-Nação, gerando uma nova forma de soberania, baseada em negócios de bilhões de dólares, quantias que os Estados não podem investir nesses processos que já fazem parte de nossa cultura.

Para Canclini (1997), essa nova dinâmica do conflito dentro do campo cultural seria uma das causas da obsolescência frequente dos bens culturais. As referências de legitimidade se sucedem velozmente, muitas vezes se sobrepondo, fazendo com que os produtores culturais tenham cada vez menos paradigmas consagrados para guiar suas ações. Para ele, o popular deixa de ser sinônimo de "local", não se constituindo mais, exclusivamente, em relação a um território ou espaço determinado, mas a partir do que é mais acessível ou que mobiliza a afetividade dos indivíduos e comunidades: "Pop, popular, popularidade: as identificações étnicas e nacionais, sem desaparecerem por completo, transbordam suas localizações em linguagens e espetáculos transnacionalizados." (CANCLINI, 2008, p. 94). Em meio ao desmantelamento de projetos nacionais, à desindustrialização ou ao abandono de muitas regiões, uma questão que se torna central no que tange às políticas e às ações culturais é o acesso às informações e conteúdos: "se trata de construir opções mais democráticas distribuídas equitativamente, para que todos possamos ter acesso ao local e ao global e combiná-lo ao nosso gosto." (CANCLINI, 2008, p. 97).

Como mencionado anteriormente, o acesso à Internet é movido, principalmente, pela busca de lazer e informação, processo fortemente ancorado pelas redes sociais, como o Facebook e o YouTube (OEI, 2014; SECOM, 2014). A utilização massiva dessas redes estende-se, inclusive, a alguns serviços públicos, como é o caso das políticas culturais. 0 risco vinculado ao potencial monopólio do Facebook pela sua utilização 
quase exclusiva em políticas culturais que preveem o acesso às redes sociais estaria na dependência gerada, tornando essas políticas e seus governos reféns de mudanças motivadas por interesses comerciais da empresa. Corporações como o Facebook e o Google representam a nêmesis dos impulsos e das experiências libertárias e de diversidade culturais possibilitados pela rede, em boa medida ilustrados pela teoria da "cauda longa", de Chris Anderson (2006), que ilustra a emergência de efetivas culturas de "nicho".

E se radicalizarmos o argumento de Anderson, no sentido de compreender a Internet como sendo, na verdade, um conjunto de culturas paralelas? As observações de Frédéric Martel (2015) apontam nessa direção. Para ele, a Internet promove uma "reterritorialização", na medida em que a Web seria muito mais local, regional, eventualmente nacional ou transnacional do que propriamente "global". Ele lembra que a expressão "comunidade" (community) em inglês não está necessariamente vinculada a um território específico, podendo remeter, ao mesmo tempo, a um grupo étnico, uma minoria sexual, uma religião ou a um bairro: “às vezes, esse 'território' assume uma forma linguística ou cultural; reflete então uma comunidade unida por interesses, afinidades ou gostos." (MARTEL, 2015, p. 417). Desse modo, as conversas e conexões propiciadas pela Internet tendem a ser muito mais delimitadas por estas "comunidades", raramente se revelando globais. Embora o tráfego de informações seja potencialmente global, possibilitado por ferramentas e aplicativos predominantemente de origem estadunidense, as conexões seriam majoritariamente locais. Entre os fatores que concorrem para isso está a produção de conteúdos nas línguas locais e nacionais, assim como o surgimento de aplicativos e serviços voltados para as especificidades culturais de cada comunidade.

Martel descreve o papel dos Estados na configuração de diferentes tipos e formas de utilização da Internet, examinando situações, entre outras, na China, no Irã, no México, na Índia, no Japão e no Brasil. 0 painel diversificado que emerge de sua análise proporciona diversos subsídios para se refletir acerca do papel dos governos e sua relação com os cidadãos, com todas as contradições daí decorrentes. 0 desafio dos Estados no cenário das redes digitais tornou-se bastante ambíguo: não podem ignorálas, mas, ao mesmo tempo, não podem se deixar capturar por elas.

0 retrato da Internet que se desenha a partir das pesquisas de Martel é de uma rede federalizada, com uma infraestrutura global e desterritorializada, e com conteúdos 
principalmente desconectados e territorializados. Ele observa, entretanto, que no caso do cinema e dos videojogos (dos entretenimentos de massa em geral), essa tendência de territorialização não se confirma totalmente. Nesse segmento específico, a Internet e o mainstream se complementam, participando de um mesmo movimento de eliminação de fronteiras e globalização de conteúdos, visando a um público "global" - tendência que não possui uma força correspondente nos setores da televisão, da música, dos livros. Para Martel, não se trata, portanto, de negar a existência de uma Internet mainstream global, de conteúdos e fluxos padronizados culturalmente; o que ele procura mostrar é "que esses conteúdos muitas vezes são superficiais e quantitativamente limitados. Além dos fluxos americanizados, existem numerosos outros streams." (MARTEL, 2015, p. 431).

Retornando a Jenkins, a partir da perspectiva de Martel, o que esse cenário proporciona, entre outras coisas, é a reprodução de alguns fenômenos descritos pelo primeiro, no âmbito estadunidense, agora em contextos culturais distintos. Observamse, assim, manifestações culturais híbridas, que vão da tentativa de reprodução mais próxima possível do original, com apenas a tradução para o idioma local, até apropriações mais livres ou transgressivas, incorporando traços culturais distintos. Nessa circulação acelerada de formas e processos culturais, as apropriações e hibridizações envolvem tanto conteúdos como formatos. Assim, comunidades de fãs de Harry Potter ou de Star Wars são encontradas em diversas partes do mundo, trocando impressões em sites, realizando convenções, produzindo fan fiction escrita e/ou audiovisual a respeito dessas produções hollywoodianas. Da mesma forma, TVs locais e regionais adaptam os formatos estadunidenses a seus contextos culturais, produzindo versões locais de programas como American Idol (música), Survivor (reality shows) ou se apropriando de gêneros audiovisuais conhecidos - sitcoms, dramas históricos, seriados policiais e até narrativas de ficção científica.

Uma contrapartida desse fenômeno é a ampliação do grau de dificuldade para a veiculação de conteúdos com menor visibilidade, embora isso não seja impossível. No caso brasileiro, por exemplo, conteúdos relacionados às culturas indígenas encontram diferentes formas de expressão, apropriando-se dos mais diversos formatos. Próximo à Dourados (MS), o grupo Brô MC's, formado por adolescentes indígenas, canta raps na língua guarani, tematizando a vida na aldeia e sua relação com a sociedade mais ampla e já preparam o segundo disco. No Acre, uma parceria entre indígenas e não indígenas, em uma equipe que reuniu programadores, artistas e antropólogos e pessoas da 
comunidade Huni Kuin, criou um videogame com a história desse grupo. 0 projeto se chama "Huni Kuin: os caminhos da jiboia", consistindo em um jogo de plataforma de cinco fases, onde cada fase conta uma antiga história desse povo. ${ }^{15}$ No Pará, a TV Cultura local, por meio de um concurso de audiovisual, viabilizou a produção de curtos episódios de animação protagonizados por quatro indígenas superpoderosas, uma mistura de desenho de heroínas com a cultura do Norte do país, baseando-se na lenda das icamiabas, amazonas que viviam em uma comunidade sem homens. ${ }^{16} \mathrm{O}$ projeto agrega situações cotidianas, contemporâneas, bem como sotaques e termos típicos regionais. Também em outros países latinos encontramos exemplos semelhantes. Na Colômbia, há Zambo Dendê, guerreiro que luta para libertar os escravos dos conquistadores portugueses e espanhóis na América Latina da época da colonização. ${ }^{17} 0$ personagem, que começou nas histórias em quadrinhos, vai virar animação e série de TV, inclusive fazendo o caminho inverso ao usual: seus direitos estão sendo negociados para distribuição nos EUA.

\section{CONSIDERAÇÕES FINAIS}

O que procuramos explorar até agora foram as conexões entre os processos que caracterizariam uma cultura da convergência, nos termos apresentados por Jenkins (2009), e os processos de apropriação cultural, com especial ênfase para as dimensões do poder e das diferenciações socioculturais. Essas dimensões, como se pode perceber, envolvem diferenciadas assimetrias sociais no que tange aos poderes político, econômico e simbólico. Embora as conceituações de cultura tradicional e/ou cultura popular não sejam o foco principal das considerações de Jenkins acerca da cultura da convergência, tendo um papel marginal em suas discussões, elas ganham um peso diferente quando pensadas em relação a contextos distintos do âmbito estadunidense; em particular, nos casos do Brasil e da América Latina.

Ao tecer suas considerações sobre a cultura popular, Jenkins (2009) está concebendo-a principalmente como o produto da indústria cultural do entretenimento,

\footnotetext{
15 Disponível em: <http://www.hypeness.com.br/2016/01/tribo-indigena-no-acre-cria-game-sobre-suapropria-historia-para-nao-deixar-morrer-sua-cultura>. Acesso em: 19 nov. 2016.

16 Disponível em: <http://papodehomem.com.br/icamiabas-amazonia-pedra-desenho-animado-paraensecurupira>. Acesso em: 19 nov. 2016.

17 Disponível em: <http://judao.com.br/zambo-dende-um-heroi-tipicamente-latinoamericano/?utm source=dlvr.it\&utm medium=facebook\#.WDC48Lkuu-Y>. Acesso em: 19 nov. 2016.
} 
veiculada e consumida massivamente por meio da mídia. Sua atenção volta-se, basicamente, sobre os efeitos da Internet e das redes colaborativas na reconfiguração dos meios de comunicação anteriores. Considera, portanto, a cultura popular como sendo aquela na qual os materiais culturais da mídia foram apropriados e integrados à vida cotidiana de seus consumidores, diferenciando-a da cultura tradicional - aquela na qual os processos de criação e apropriação ocorrem num nível alternativo e não comercial, no qual a troca de bens caracteriza-se muito mais por uma economia da dádiva e onde seus criadores extraem seus materiais de imagens e tradições compartilhadas. Como pudemos perceber, a partir das observações de Canclini (1997), Martín-Barbero (1997) e Ortiz (1988), em conexão com algumas de suas ideias, no caso latino-americano entram em jogo outras dinâmicas históricas e conceituais, sendo particularmente importante nesse contexto o papel ainda forte das culturas tradicionais e aquele historicamente desempenhado pelo Estado.

Assim, embora a ideia de uma cultura da convergência seja pertinente como descrição de um processo cultural global, envolvendo a apropriação cultural mediada pelas tecnologias, características e condições decorrentes das especificidades locais influenciam essa dinâmica. Os breves exemplos de apropriações e hibridizações mencionados anteriormente mostram que se trata de um processo bastante diferenciado, que envolve diversas possibilidades e estratégias. No caso do Brasil (que, acreditamos, pode ser correlacionado aos demais países da América Latina), o exemplo talvez mais evidente dessas "mixagens" culturais seja a música: a incorporação do rap ao cotidiano das periferias paulistanas, a presença dos ritmos caribenhos na guitarrada paraense, os elementos percussivos do maracatu somados às guitarras roqueiras do manguebit. A diversidade de conteúdos e formatos disponíveis nas redes infocomunicacionais, somada às facilidades proporcionadas pelo formato digital para sua manipulação e reconfiguração, possibilita a hibridização e a recriação cultural por parte dos indivíduos e grupos, gerando distintas possibilidades de apropriação cultural no âmbito de uma cultura da convergência.

Enxergamos as plataformas colaborativas de financiamento coletivo, no nosso caso mais especificamente a de crowdfunding, como um ambiente que se tornou possível pelo uso das TICs, principalmente a Internet. Sua formulação partiu da constatação de que vivemos nos tempos de valorização da participação, onde os processos de trocas informacionais são de extrema importância para o fortalecimento da rede. 
Necessariamente, essas plataformas dependem de informações e capital social, nesse caso vemos o Catarse como uma plataforma que reúne as duas coisas. Por um lado, ele funciona como um catálogo de projetos culturais; por outro, funciona como uma rede sociotécnica na qual o capital social de um realizador pode entrar em sinergia com outros produtores e também com os públicos. Na busca de entendermos como as TICs podem influenciar as estratégias e táticas de produção, circulação e consumo cultural, vemos as plataformas como o Catarse surgirem como uma alternativa viável. Essas iniciativas de práticas colaborativas têm se mostrado uma promissora ferramenta para a produção e organização cultural.

Por outro lado, se é possível perceber a ampliação da circulação de conteúdos diversificados, culturalmente enraizados, criando circuitos paralelos ou culturas de nicho, a indústria cultural ainda mantém - e luta para manter - a sua hegemonia. Como mostram as observações de Martel (2015), esta constatação é particularmente verdadeira para alguns campos, como os das indústrias do audiovisual e dos videogames.

Nesse sentido, acreditamos que o papel do Estado, particularmente em países latino-americanos e no Brasil - e aqui concordamos com Yúdice (2015) -, não é o de se "intrometer" demais nesses processos culturais, no sentido de um dirigismo estatal, mas simultaneamente facilitar que aquelas expressões culturais, que não possuem o "valor de mercado", consigam se viabilizar e se tornar visíveis, capacitando-as, no limite, até serem eventualmente assumidas pelas marcas comerciais e obterem seu apoio. Ou seja, proporcionar que elas possuam o mesmo tipo de chance ou compartilhem um mesmo horizonte de possibilidades, e no qual prosperem as expressões locais. No cenário, contemporâneo, trata-se de um desafio múltiplo, que envolve conciliar os impulsos locais, nacionais e globais, fomentando a produção, a qualidade, a distribuição, a circulação e a apropriação dessas expressões. Nesse domínio da diversidade, os processos colaborativos de mediação cultural e da informação, característicos da cultura da convergência, seriam ainda mais importantes no sentido de estabelecer estratégias para viabilizar, facilitar e/ou proporcionar o acesso a essas produções. A consideração dessas dinâmicas no desenho e na proposição de ações e políticas culturais torna-se um fator estratégico para sua apropriação por parte dos sujeitos.

$\mathrm{O}$ conjunto de considerações e questionamentos relativos às tecnologias digitais $\mathrm{e}$ às redes colaborativas aqui desenvolvido aponta que sua presença, mesmo que 
problemática, enriquece e disponibiliza novos meios e recursos para a criação cultural e para a dinamização das relações sociais. O grau de autonomia e as condições socioculturais dadas para a apropriação da informação e dos usos das tecnologias variam contextualmente. Desse modo, discutir o impacto gerado pelas tecnologias digitais e, em particular, pelas redes sociais colaborativas, nas possibilidades de acesso, circulação e expressão cultural, implica em repensar as modalidades de comunicação e de mediação tradicionais presentes nas ações e políticas culturais.

\section{REFERÊNCIAS}

ALMEIDA, Marco Antônio de. Processos culturais \& convergências tecnosociais. Revista do Centro de Pesquisa e Formação do SESC, São Paulo, n. 2, p. 142-158, maio 2016. . Mediações tecnosociais e mudanças culturais na Sociedade da Informação. Revista Em Questão, Porto Alegre, v. 16, n. 1, p. 113-130, jan./jun. 2010.

Informação, tecnologia e mediações culturais. Revista Perspectivas em Ciência da Informação, Belo Horizonte, v. 14, n. especial, p. 184-200, 2009.

ALVES, Uéliton dos Santos. Redes sociotécnicas e novas formas de comunicação, organização e produção cultural. 2014. Trabalho de Conclusão de Curso (Graduação) - Faculdade de Filosofia, Ciências e Letras de Ribeirão Preto, Universidade de São Paulo, Ribeirão Preto, 2014.

ANDERSON, Chris. Cauda longa: do mercado de massa para o mercado de nicho. Rio de Janeiro: Elsevier, 2006.

BRETON, P.; PROULX, S. Sociologia da Comunicação. São Paulo: Loyola, 2002.

CANCLINI, Néstor Garcia: Culturas híbridas: estratégias para entrar e sair da modernidade. São Paulo: Edusp, 1997. 2008.

. Latino-americanos à procura de um lugar neste século. São Paulo: Iluminuras,

CARUSO, Felipe. A marca de 1.000 projetos financiados e o aprendizado de quem não chegou lá. 29/04/2014. Blog Catarse. Disponível em: <http://blog.catarse.me/a-marcade-1-000-projetos-financiados-e-o-aprendizado-de-quem-nao-chegou-la/\#more$23554580834>$. Acesso em: 29 maio 2016.

CASTELLS, Manuel. Internet e sociedade em rede. In: MORAES, Denis de (Org.). Por uma outra comunicação: mídia, mundialização cultural e poder. Rio de Janeiro: Record, 2003. p. $255-288$. 
CATARSE E CHORUS. Retrato do financiamento coletivo no Brasil 2013/2014, 2014. Disponível em: <http://pesquisa.catarse.me/\#/01>. Acesso em: 29 maio 2016.

ESTELLÉS-AROLAS, Enrique; GONZÁLEZ-LADRÓN-DE-GUEVARA, Fernando. Towards an integrated crowdsourcing definition. Journal of Information Science, p. 1-14, 2012. Disponível em: <http://www.crowdsourcing-blog.org/wpcontent/uploads/2012/02/Towards-an-integrated-crowdsourcing-definitionEstell\%C3\%A9s-Gonz\%C3\%A1lez.pdf>. Acesso em: 18 nov. 2016.

GABLER, Neal. Vida, o filme: Como o entretenimento conquistou a realidade. São Paulo: Companhia das Letras, 1999.

HARDT, Michael; NEGRI, Antonio. Multidão - Guerra e Democracia na Era do Império. Rio de Janeiro: Record, 2005.

HOWE, J. 0 poder das Multidões. Rio de Janeiro: Elsevier, 2009.

JENKINS, Henry. Cultura da convergência. 2. ed. São Paulo: Aleph, 2009.

LÉVY, Pierre. Cibercultura. São Paulo: Editora 34, 1998.

A revolução contemporânea em matéria de comunicação. In: MARTINS, F. M.; SILVA, J. M. da (Org.) Para navegar no século XXI: tecnologias do imaginário e cibercultura. Porto Alegre: Sulina, 2000. p. 195-216.

LUKES, Steve. O Poder: uma visão radical. Brasília: Cadernos UNB/Ed. UNB, 1980.

MARTEL, Frédéric. Smart: o que você não sabe sobre a internet. Rio de Janeiro: Civilização Brasileira, 2015.

MARTÍN-BARBERO, Jesus. Dos meios às mediações - comunicação, cultura e hegemonia. Rio de Janeiro: Ed. UFRJ, 1997.

MELUCCI, Alberto. A invenção do presente: movimentos sociais nas sociedades complexas. Petrópolis, RJ: Vozes, 2001.

OEI - Organización de Estados Iberoamericanos para la Educación, la Ciência y la Cultura. Encuesta Latinoamericana de Hábitos e Prácticas Culturales 2013. Madrid, 2014.

ORTIZ, Renato. A moderna tradição brasileira. São Paulo: Brasiliense, 1988.

POSTMAN, Neil. Tecnopólio - A rendição da Cultura à Tecnologia. São Paulo: Nobel, 1994.

PRIMO, Alex. A grande controvérsia: trabalho gratuito na Web 2.0. In: RIBEIRO, J. C.; BRAG, V.; SOUSA, P. V. (Org.) Performances interacionais e mediações sociotécnicas. Salvador: EDUFBA, 2015. p. 57-85. 
SANTOS, Andre Pequeno dos. Piratas, anarquistas ou publicizadores? Práticas socioinformacionais, cultura livre e domínio público. 2014. Dissertação (Mestrado em Cultura e Informação) - Escola de Comunicações e Artes, Universidade de São Paulo, São Paulo, 2014.

SCOLARI, Carlos. Narrativas Transmídias: Consumidores implícitos, mundos narrativos e branding na produção da mídia contemporânea. Revista PARÁGRAFO, São Paulo, v. 1, n. 3, p. 7-19, jan./jun. 2015.

SECOM - Secretaria de Comunicação Social da Presidência da República. Pesquisa Brasileira de Mídia 2015 - Hábitos de Consumo de Mídia pela População Brasileira. Brasília, 2014. Disponível em:

<http://www.secom.gov.br/atuacao/pesquisa/lista-de-pesquisas-quantitativas-equalitativas-de-contratos-atuais/pesquisa-brasileira-de-midia-pbm-2015.pdf >. Acesso em: $1^{\circ}$ jun. 2015.

SHIRKY, Clay. Lá vem todo mundo: o poder de organizar sem organizações. Rio de Janeiro: Zahar, 2012.

SILVEIRA, Sérgio Amadeu. Cibercultura, commons e feudalismo informacional. Revista FAMECOS, Porto Alegre, n. 37, p. 85-90, dez. 2008.

UOL. Estúdio quer proibir fan-film de "Star Trek" por ser muito profissional. UOL Entretenimento. São Paulo, 30 dez. 2015. Disponível em: $<$ http://cinema.uol.com.br/noticias/redacao/2015/12/30/estudio-quer-proibir-fanfilm-de-star-trek-por-ser-muito-profissional.htm>. Acesso em: 2 jan. 2016.

VALIATI, Vanessa Amália Dalpizol. Crowdfunding no cinema brasileiro: um estudo sobre o uso do financiamento coletivo em obras audiovisuais brasileiras de baixo orçamento. 2013. Dissertação (Mestrado) - Curso de Comunicação Social, Faculdade de Comunicação Social / Programa de Pós-Graduação em Comunicação Social, Pontifícia Universidade Católica do Rio Grande do Sul, Porto Alegre, 2013.

YÚDICE, George. A conveniência da cultura: usos da cultura na era global. Belo Horizonte: Ed. UFMG, 2006.

Internet en manos de sectores privados hoy está disputando el poder a los Estados. Entrevista a Karina Wroblewski. La Nación, Argentina, 17 maio 2015. Disponível em: <http://www.lanacion.com.ar/1792906-internet-hoy-esta-disputandoel-poder-a-los-estados Acesso em 01/06/2015>. Acesso em: 19 nov. 2016.

\section{AGRADECIMENTOS}

O autor agradece a Uéliton dos Santos Alves e a André Pequeno dos Santos, cujas pesquisas contribuíram decisivamente para as discussões desenvolvidas neste artigo acerca de financiamento coletivo, formatos colaborativos e HQs. 


\section{SOBRE O AUTOR}

\section{Marco Antônio de Almeida}

Doutor em Ciências Sociais pela Unicamp e Livre-Docente em Ciências da Informação (USP, 2015). Professor do Curso de Biblioteconomia e Ciência da Informação (FFCLRP-USP) e do Programa de PósGraduação em Ciência da Informação (ECA-USP).

E-mail: marcoaa@ffclrp.usp.br

Recebido em: 14/06/2016; Aceito em: 17/11/2016.

\section{Como citar este artigo}

ALMEIDA, Marco Antônio de. Redes sociotécnicas, convergências e práticas de consumo cultural. Informação em Pauta, Fortaleza, v. 1, n. 2, p. 09-40, jul./dez. 2016. 